\title{
Peranan Sanggar Tarara dalam pelestarian Tari Tandhang
}

\author{
Yuliana, Margono*, Edi Suhartono \\ Universitas Negeri Malang, Jl. Semarang No. 5 Malang, Jawa Timur, Indonesia \\ *Penulis korespondensi, Surel: margono.fis@um.ac.id
}

Paper received: 02-03-2021; revised: 15-03-2021; accepted: 30-03-2021

\begin{abstract}
This study aims to describe the values of the Tandhang dance, explain the role of the Tarara Studio, obstacles, and solutions to obstacles in the preservation of the Tandhang dance in Bangkalan Regency. This study uses a qualitative approach to the type of descriptive research. Data collection was carried out by means of interviews, observation, and documentation. Data analysis used interactive analysis by Miles and Huberman. Tandhang dance has good values which are used as life guidelines for the Madurese, the role of the Tarara Studio is very good in preserving the Tandhang dance with training and staging, the obstacles faced are, delays, differences in ability, laziness, outside culture, differences in public opinion. The solutions taken were reminding, dividing groups, motivating oneself, attracting interest, and accepting differences of opinion.
\end{abstract}

Keywords: role; Tarara Studio; Tandhang Dance

\begin{abstract}
Abstrak
Kajian ini bertujuan untuk mendeskripsikan nilai-nilai tari Tandhang, menjelaskan peranan Sanggar Tarara, hambatan, dan solusi dari hambatan dalam pelestarian tari Tandhang di Kabupaten Bangkalan. Kajian ini menggunakan metode pendekatan kualitatif dengan jenis penelitian deskriptif. Pengumpulan data dilakukan dengan cara wawancara, observasi, dan dokumentasi. Analisis data menggunakan analisis interaktif milik Miles dan Huberman. Tari Tandhang memiliki nilai-nilai baik yang dijadikan sebagai pedoman hidup orang Madura, peranan Sanggar Tarara sangat baik dalam pelestarian tari Tandhang dengan pelatihan dan pementasan, hambatan yang dihadapi yaitu, keterlambatan, perbedaan kemanpuan, malas, budaya luar, perbedaan pendapat masyarakat. Solusi yang diambil yaitu, mengingatkan, membagi kelompok, memotivasi diri, menarik minat, dan menerima perbedaan pendapat.
\end{abstract}

Kata kunci: peranan; Sanggar Tarara; Tari Tandhang

\section{Pendahuluan}

Bangkalan merupakan salah satu kabupaten di Madura yang memiliki banyak kesenian tradisional yang beragam dan bernilai. Kesenian yang ada di Bangkalan diantaranya yaitu tari Tandhang Bangkalan. Selain memiliki banyak kesenian Madura juga dikenal dengan masyarakatnya yang menjunjung tinggi agama, tradisi tolong menolong dan gotong royong, saling menghormati, hemat, disiplin, rajin, dan bekerja keras (Hidayat, 105-106). Kebudayaan sendiri di Indonesia merupakan salah satu kekayaan yang dimiliki sehingga muncullah Undang-Undang No. 5 tahun 2017 tentang Pemajuan Kebudayaan. Tujuan dibuatnya UU No. 5 tahun 2017 ini adalah untuk mengembangkan nilai-nilai luhur budaya bangsa, memperkaya keberagaman budaya, memperteguh jati diri bangsa, memperteguh persatuan dan kesatuan bangsa, mencerdaskan kehidupan bangsa, meningkatkan citra bangsa, mewujudkan masyarakat madani, meningkatkan kesejahteraan rakyat, melestarikan warisan budaya bangsa, dan mempengaruhi arah perkembangan peradaban dunia sehingga kebudayaan menjadi haluan pembangunan nasional. 
Salah satu unsur pendukung yang dapat mempertahankan eksistensi kesenian tradisional adalah kepemilikan sanggar. Sanggar mulanya sebagai wadah atau tempat untuk bernaungnya kesenian tradisional. Di tempat ini para pelaku seni berkumpul, berlatih, dan berdiskusi seputar kesenian yang mereka geluti. Sanggar ini pun bisa berfungsi sebagai tempat untuk mempersiapkan dan mengatur strategi. Sanggar adalah suatu tempat atau sarana yang digunakan oleh suatu komunitas atau sekumpulan orang untuk melakukan suatu kegiatan (Purnama, 2015: 462). Komponen yang dapat menunjang kehidupan seni meliputi seniman sebagai karya, karya seni yang merupakan bentuk nyata dari suatu karya seni yang dapat dihayati, dinikmati dan ditangkap dengan pancaindera dan penghayat yaitu masyarakat konsumen tari (Sutopo dalam Hartono, 2000: 45-46). Sanggar Tarara merupakan sebuah sanggar yang ada di bangkalan. Sanggar Tarara merupakan sebuah organisasi lembaga pendidikan non formal yang berorientasi di bidang kesenian didirikan oleh bapak Sudarsono dan sudah mengadakan latihan sejak tahun 1986. Terdapat beberapa bidang dalam sanggar ini salah satunya yaitu bidang tari. Tari merupakan satu diantara seni-seni yang mendapatkan perhatian cukup besar dari masyarakat. Oleh karena tari ibarat bahasa gerak merupakan alat ekspresi dan komunikasi yang umum, yang bisa dilakukan dan dinikmati oleh siapa saja, kapan saja dan dimana saja. Gerakan pada tari bukan hanya sekedar gerak biasa. Gerak adalah pengalaman fisik yang paling elementer dari kehidupan manusia. Gerak tidak hanya terdapat pada denyutan-denyutan di seluruh tubuh manusia untuk tetap dapat memungkinkan manusia hidup, tetapi gerak juga terdapat pada ekspresi dari segala pengalaman emosional manusia (John Martin dalam Soedarson 1978: 1). Dalam kesenian tari terdapat banyak regam gerak yang disajikan. Penari harus dapat menjiwai setiap gerakan yang dibawakan agar dapat menguasai dengan baik tari yang dibawakan.

Telah banyak karya-karya yang telah dihasilkan oleh Sanggar Tarara salah satunya yaitu tari Tandhang. Tari ini merupakan tari yang bersumber dan sekaligus hasil revitalisasi dari kesenian Sandur Bangkalan. Kesenian Sandur merupakan kesenian turun temurun yang saat ini sudah jarang ditemui pertunjukannya di masyarakat. Pentingnya revitalisasi budaya lokal disebabkan kehidupan masyarakat yang didasarkan pada kultur masa lampau, kenyataannya lebih baik jika dibandingkan dengan kehidupan masyarakat sekarang yang banyak menyerap budaya luar setiap saat (Sutiyono \& Seriati, 2013: 31). Dalam menghadapi perubahan budaya saat ini hal yang perlu dilakukan adalah dengan melakukan eksplorasi yang bersifat inventif, inovasi yang rasional, dan bisa berlangsung secara terus menerus dan pada akhirnya akan memperkaya budaya kita (Tindaon, 2012). Tari Tandhang bukan hanya sebuah tari melainkan juga terdapat nilai-nilai yang terkandung didalamnya. Secara sederhana dapat dikatakan bahwa nilai merupakan sebuah ide atau konsep tentang sesuatu yang penting dalam kehidupan seseorang dan menjadi perhatiannya. Sebagai standar perilaku, tentunya nilai menuntut seseorang untuk melakukan seperti telah diungkapkan tersebut. Konsekuensi dari pemahaman akan nilai seperti diutarakan tersebut, menjadikan nilai itu secara praktis sebagai standar perilaku yang menjadikan orang berusaha untuk hidup sesuai dengan nilai-nilai yang telah di yakininya, sekalipun pada sebagian orang ditemukan kurang dalam pengertian tidak selamanya menyadari nilai yang di milikinya, sehingga menjadikannya terperosok pada perilaku yang berseberangan dengan prespektif nilai (Salfia, 2015).

Peranan Sanggar Tarara dalam pelestarian tari Tandhang sangat penting agar nilai dan pesan yang ada dapat tersampaikan dan tidak hilang. Peranan yang berasal dari kata peran merupakan aspek dinamis kedudukan (status), apabila seseorang melaksanakan hak dan kewajibannya sesuai dengan, maka ia menjalankan suatu peranan. Dalam sebuah organisasi 
setiap orang memiliki berbagai macam karakteristik dalam melaksanakan tugas, kewajiban atau tanggung jawab yang telah diberikan oleh masing-masing organisasi atau lembaga (Lantaeda, Lengkong \& Ruru, 2002: 243). Peranan juga dapat membimbing seseorang dalam berperilaku, karena fungsi peran sendiri adalah sebagai berikut: 1) Memberi arah pada proses sosialisasi; 2) Pewarisan tradisi, kepercayaan, nilai-nilai, norma-norma dan pengetahuan; 3) Dapat mempersatukan kelompok atau masyarakat; dan 4) Menghidupkan sistem pengendali dan kontrol, sehingga dapat melestarikan kehidupan masyarakat (Narwoko dan Suyanto dalam Pertiwi, Suntoro \& Nurmalisa, 2017). Dalam pelestarian kegiatan atau yang dilakukan secara terus menerus, terarah dan terpadu guna mewujudkan tujuan tertentu yang mencerminkan adanya sesuatu yang tetap dan abadi, bersifat dinamis, luwes, dan selektif (Jacobus dalam Khutniah \& Venonica, 2012). Pelestarian budaya adalah upaya untuk mempertahankan nilai-nilai seni budaya, nilai tradisional dengan mengembangkan perwujudan yang bersifat dinamis, luwes dan selektif, serta menyesuaikan dengan situasi dan kondisi yang selalu berubah dan berkembang (Hildigardis, 2019: 171-172).

Globalisasi yang terjadi saat ini memang sangat berpengaruh terhadap kehidupan masyarakat salah satunya yaitu dalam bidang sosial kebudayaan. Berbagai masalah yang timbul dari perkembangan globalisasi yaitu diantaranya hilangnya budaya asli suatu daerah, hilangnya sifat kekeluargaan dan sosial, hilangnya nilai-nilai budaya, kehilangan kepercayaan diri, dan lain-lain. selain globalisasi lunturnya minat tari tradisi juga dapat disebabkan oleh beberapa faktor yaitu westernisasi, modernisasi, tren masa kini, perkembangan zaman, dan gengsi yang tinggi. Hal tersebut menjadi penghambat dalam proses pelestarian tari. Hambatan ini menjadi sebuah rintangan seseorang dalam melakukan kegiatan tertentu (Suyedi \& Idrus, 2019: 124). Untuk menhadapi hambatan maka diperlukan solusi yang harus diambil oleh Sanggar Tarara. solusi adalah cara atau jalan yang digunakan untuk memecahkan atau menyelesaikan masalah tanpa adanya tekanan. Tekanan yang dimaksud disini yaitu dalam mencari solusi tidak memaksakan pada pendapat pribadi melainkan berpedoman pada kaidah atau aturan yang ada (Chatib, 2011). Selain itu dalam pengambilan keputusan diperlukan stategi. strategi adalah sebuah tindakan aksi atau kegiatan yang dilakukan oleh seseorang atau perusahaan untuk mencapai sasaran atau tujuan baik jangka pendek maupun jangka panjang yang telah ditetapkan dalam menghadapi masalah atau hambatan yang datang baik dari dalam maupun luar perusahaan (Zulfajri, 2017: 85)

Berdasarkan paparan diatas, peneliti tertarik untuk mengkaji lebih dalam tentang pelestarian tari Tandhang di Kabupaten Bangkalan melalui penelitian dengan menggali informasi yaitu, (1) apa saja nilai-nilai yang terdapat dalam tari Tandhang, (2) bagaimana peranan Sanggar Tarara dalam pelestarian Tari Tandhang di Kabupaten Bangkalan, (3) bagaimana hambatan-hambatan Sanggar Tarara dalam pelestarian tari Tandhang di Kabupaten Bangkalan, dan (4) bagaimana solusi dari hambatan-hambatan Sanggar Tarara dalam pelestarian tari Tandhang.

\section{Metode}

Pada kajian ini peneliti menggunakan pendekatan kualitatif. Penelitian kualitatif adalah penelitian yang menghasilkan prosedur analisis yang tidak menggunakan prosedur analisis statistik atau cara kuantifikasi lainnya Moleong (2007: 6). Penelitian kualitatif didasarkan pada upaya membangun pandangan mereka yang diteliti yang rinci. Adapun jenis penelitian yang dipakai sebagai bagian dari penelitian kualitatif. Peneliti memakai jenis penelitian deskriptif dikarenakan penelitian ini mengamati kegiatan-kegiatan di Sanggar Tarara secara faktual dan 
sistematis. Penelitian deskriptif dimaksudkan untuk menyelidiki keadaan, kondisi atau hal-hal lain (keadaan, kondisi, situasi, peristiwa, kegiatan) yang hasilnya dipaparkan dalam bentuk laporan penelitian (Arikunto dalam Fhata \& Ismawan, 2018: 70-71).

Data yang didapat dalam penelitian bersumber dari (1) wawancara dengan pihak-pihak yang terkait dengan Sanggar Tarara yaitu ketua Sanggar Tarara, anggota pengelola, pelatih tari, dan murid tari Sanggar Tarara. kemudian pihak yang tidak terkait dengan Sanggar Tarara yaitu pedagang di sekitar lokasi Sanggar Tarara. (2) Peristiwa, peneliti mengamati proses pelatihan tari di Sanggar Tarara dan evaluasi sekaligus pemberian info setelah latihan. (3) Dokumen, peneliti menggunakan dokumen berupa foto-foto mengenai Sanggar Tarara, buku absensi siswa tari Sanggar Tarara, dan buku biodata anggota Sanggar Tarara.

Pada penelitian ini perosedur pengumpulan data yaitu wawancara, observasi, dan dokumentasi. Data dianalisi dengan teknik interaktif dari yaitu reduksi data, penyajian data, dan verifikasi atau penarikan kesimpulan. Adapun pengecekan keabsahan data dilakukan dengan pengecekan ulang terhadap hasil penelitian dan membandingkan hasil wawancara beberapa narasumber yang ternyata sama atau triangulasi.

\section{Hasil dan Pembahasan}

\subsection{Nilai-Nilai Tari Tandhang}

Menurut temuan peneliti tari Tandhang merupakan tari yang bersumber sekaligus hasil dari revitalisasi kesenian Sandur Bangkalan yang digarap oleh Bapak Sudarsono. Penelitian kesenian Sandur dan penggarapan ke dalam seni tari merupakan proses revitalisasi. Sedangkan tari Tandhang merupakan produk dari hasil revitalisasi kesenian Sandur Bangkalan. Konsep revitalisasi menjadi pilihan yang tepat untuk menyelamatkan peninggalanpeninggalan yang dianggap sebagai warisan budaya atau culture heritage. Konsep revitalisasi menjadi suatu tindakan baik "proses" maupun "prodak". Proses artinya suatu tindakan atau action bagaimana cara perlakuan itu harus dikerjakan, sementara prodak adalah hasil dari proses yang sudah dilakukan, sehingga mnghasilkan sesuatu sesuai dengan yang diinginkan (Hadi, 2018: 1).

Tari Tandhang yang digarap dari kesenian Sandur memiliki nilai yang dijadikan landasan oleh orang Madura dalam menjalani kehidupannya. Nilai-nilai tersebut telah dianggap menjadi landasan filosofi bagi orang Madura. Nilai merupakan sesuatu yang memberi makna pada hidup, yang memberi acuan, titik tolak dan tujuan hidup (Adisusilo, 2012: 57). Jadi nilai dalam tari Tandhang merupakan nilai yang digarap dari kesenian Sandur dan sumbernya dari kehidupan orang Madura sendiri. Nilai tersebut dijadikan sebuah kesenian agar orang Madura tidak melupakan nilai-nilai asli dalam kehidupannya karena perkembangan zaman yang tentunya juga akan membawa perubahan bagi pemikiran orang Madura.

\subsubsection{Nilai Dinamis}

Madura memang terkenal dengan keislamannya yang kental. Maka tak heran terdapat banyak pondok disana. Agama memang sangat penting karena merupakan pondasi dalam menjalani kehidupan. Orang tua bahkan lebih memilih anaknya dimasukkan ke pesantren dari pada menyekolahkannya sampai jenjang tinggi. Karena mengganggap bahwa belajar agama 
lebih penting sebagai bekal dikehidupannya kelak dari pada harus belajar tinggi-tinggi namun pada akhirnya tidak mengerti tentang agama.

\subsubsection{Nilai Moral}

Pertama, gigih dalam berusaha. Kegigihan orang Madura dalam berusaha memang sangat besar. Dalam menjalani kehidupannya tentu akan jatuh bangun namun dari situlah biasanya mereka akan bangkit dan belajar dari kesalahan. Selain itu orang Madura biasanya akan lebih memilih merantau untuk bekerja di kota orang kebanyakan sebagai pedangang bahkan ada yang berprinsip tidak pulang kampung sebelum menjadi sukses. Dan itu semua tidak lepas dari ajaran agama yang mereka pegang teguh.

Kedua, menjaga diri. Orang Madura sangat memandang tinggi harga diri mereka karena harga diri merupakan hal yang penting. Apabila ada seseorang yang merendahkan harga diri mereka maka mereka tidak akan tinggal diam. Walaupun orang Madura terkenal dengan ucapannya yang jujur atau lebih tepatnya bicara sesuai dengan apa yang mereka lihat. Mereka akan lebih berhati-hati dengan lawan bicaranya agar tidak tersinggung.

Ketiga, Orang Madura sangat menghormati orang lain terutama orang tua mereka. Karena orang tua merupakan orang yang harus dipatuhi sesuai dengan ajaran agama. Terutama seorang ibu karena mereka percaya bahwa surga ada dibawah telapak kaki ibu dan mereka tidak boleh menyakitinya sebab kesuksesan anak juga berasal dari doa orang tua terutama ibu. Selain orang tua mereka juga menghormati orang yang lebih tua, guru, kiyai, pemerintah dan lainnya. Bahkan kiyai adalah orang yang sangat mereka hormati setelah orang tua mereka.

Keempat, mendahului berbuat baik. Walaupun orang Madura terlihat keras tetapi mereka suka melakukan kebaikan. Kebaikan tersebut mereka lakukan baik terhadap orang yang mereka kenal maupun yang tidak mereka kenal karena mereka mengganggap bahwa mereka semua adalah saudara.

Berdasarkan temuan peneliti, nilai yang terdapat dalam tari Tandhang diambil dari kepribadian orang Madura itu sendiri. Nilai tersebut bahkan menjadi filosofi yang dipakai oleh orang Madura dalam kehidupan sehari-hari karena dianggap baik dan berharga yaitu nilai dinamis dan nilai moral yang terdiri dari gigih dalam berusaha, menjaga diri, menghargai orang lain, dan mendahului berbuat baik. Sesuatu bisa dikatakan mempunyai nilai apabila ia bermanfaat dan layak dalam kaca mata manusia yang memberikan penilaian (Suyatno, 2012: 36). Nilai yang digambarkan pada tari Tandhang diambil dari kepribadian orang Madura itu sendiri artinya orang Madura memiliki standar perilaku yang baik dalam kesehariannya seperti dalam hidup harus selalu berpegang teguh pada agama, dalam memenuhi kebutuhan hidupnya orang Madura harus gigih dan berusaha dengan keras, menjaga harga diri dengan tidak melakukan hal-hal yang tidak baik, dan selalu mendahului berbuat baik kepada orang lain baik yang dikenal maupun yang tidak dikenal. Konsekuensi dari pemahaman akan nilai seperti diutarakan tersebut, menjadikan nilai itu secara praktis sebagai standar perilaku yang menjadikan orang berusaha untuk hidup sesuai dengan nilai-nilai yang telah di yakininya, sekalipun pada sebagian orang ditemukan kurang dalam pengertian tidak selamanya menyadari nilai yang di milikinya, sehingga menjadikannya terperosok pada perilaku yang berseberangan dengan prespektif nilai (Salfia, 2015). 
Nilai pada tari Tandhang selain menjadi standar perilaku juga menjadi indikator bagi orang Madura. Indikator tersebut diantaranya yaitu: (1) Memberikan tujuan atau arah bagi orang Madura. (2) Memberikan aspirasi untuk melakukan hal yang positif. (3) Mengarahkan untuk bertingkahlaku yang baik sesuai dengan yang diajarkan oleh kyai, orang tua, guru dan lainnya. (4) Menarik orang Madura untuk merenungkan nilai filosofi tersebut. (5) Dapat mengusik perasaanya. (6) Nilai filosofi tersebut terkait dengan kepercayaan orang Madura yang harus selalu mengutamakan sang Pencipta. (7) Nilai filosofi itu muncul karena adanya kesadaran orang Madura yang harus memiliki landasan dalan menjalankan kehidupannya.

Ada beberapa indikator dalam nilai yaitu, (1) Nilai memberi tujuan atau arah (goals or purposes) kemana kehidupan harus menuju, harus dikembangkan. (2) Nilai memberi aspirasi (aspirations) atau aspirasi kepada seseorang untuk hal yang berguna, yang baik, yang positif bagi kehidupan. (3) Nilai mengarahkan seseorang untuk bertingkah laku, atau bersikap sesuai dengan moralitas masyarakat, jadi nilai itu diberi acuan atau pedoman bagaimana seharusnya seseorang harus bertingkah laku. (4) Nilai itu menarik, memikat hati seseorang untuk dipikirkan, untuk direnungkan untuk dimiliki untuk dihayati. (5) Nilai mengusik perasaan. (6) Nilai terkait dengan keyakinan atau kepercayaan seseorang. (7) Nilai biasanya muncul karena adanya kesadaran (Adisusilo, 2012: 58).

\subsubsection{Ragam Gerak Tari Tandhang}

Gerakan tari Tandhang digarap dari kesenian Sandur Bangkalan yang merupakan kesenian semacam arisan namun pemainnya adalah laki-laki yang berdandan seperti wanita. Gerakannya jika dilihat akan terlihat seperti gerakan pencak silat dimana ketika membawakannya penari harus energik. Gerakan-gerakan pada tari Tandhang diantaranya yaitu, sembah, bumi langit, tanjaan, sepak terjang, tangan kebawah, ceklekan, tangan kanan depan dada dan tangan kiri di atas, semedi, tatapan mata ke depan, perlahan berbalik ke depan dengan kaki kanan jinjit, lurus ke depan, tumpuan kaki belakang rendah tinggi secara bergantian, melangkah harus melihat kanan kiri, melompat-lompat, kaki dan badan menghadap kanan pandangan ke depan, bergelombang, menuju titik akhir kehidupan, berguling, bangkit setelah jatuh, dan sembahan. Gerakan tersebut memiliki makna yang berbeda beda namun saling berkaitan.

Menurut hasil temuan peneliti gerak dalam tari Tandhang bukan hanya sekedar gerakan saja melainkan menjadi perantara untuk menyampaikan bagaimana filosofi yang dipakai oleh orang Madura. Setiap gerakannya sarat akan makna yang juga ditunjukkan dari ekspresi si penari. Penari harus bisa menjiwai setiap geraknya karena pembawaannya harus berenergik. Hal ini karena gerakan tari Tandhang hampir sama dengan gerakan pencak silat silat. Gerak adalah pengalaman fisik yang paling elementer dari kehidupan manusia. Gerak tidak hanya terdapat pada denyutan-denyutan diseluruh tubuh manusia untuk tetap dapat memungkinkan manusia hidup, tetapi gerak juga terdapat pada ekspresi dari segala pengalaman emosional manusia (John Martin dalam Soedarsono, 1978: 1).

Jadi gerakan-gerakan dalam tari Tandhang berasal dari pengalaman orang Madura dalam menjalani kehidupannya sehari-hari. Gerakan tersebut memiliki makna filosofi di dalamnya yang dijadikan pedoman dalam menjalani kehidupan karena dianggap bernilai, baik, pantas. Dijadikan sebuah tari agar nilai-nilai tersebut dapat tersampaikan dan tidak luntur karena perkembangan zaman yang mempengaruhi pola pikir orang Madura dalam menjalani 
kehidupannya sehingga walaupun banyak budaya luar mulai masuk orang Madura tetap memiliki pendirian yang teguh

\subsubsection{Busana Tari Tandhang}

Pesa'an dan gomrongan merupakan baju dan celana yang longgar dan berwarna hitam. Pakaian ini merupakan pakaian khas laki-laki Madura sebagai identitas mereka. Pakaian ini masih sering digunakan bahkan ketika menghadiri acara adat.

Kaos merah putih yang dipakai sebagai dalaman dari Pesa'an ini juga merupakan kaos khas orang Madura. Kaos ini memiliki makna tersendiri yaitu semangat juang yang tinggi. Bahkan orang Madura yang merantaupun tidak akan malu untuk mengenakan kaos ini sebagai identitas mereka.

Ikat kepala yang dipakai disini adalah odheng kerakyatan karena tari Tandhang juga merupakan tari Kerakyatan. Odheng ini merupakan lipatan kain tanpa ada penutup kepala. Kemudian ada bentuk seperti buntut kalajengking. Buntut kalajengking ini lah yang diibaratkan dengan orang Madura yaitu diam tetapi jika diganggu maka akan disengat.

Palam busana tari Tandhang telah terdapat pengembangan. Perkembangan tersebut merupakan tuntutan yang harus mereka hadapi. Pengembangan ini juga menjadi jalan keluar untuk menarik perhatian masyarakat terutama anak muda ketika melihat pertunjukan tari tandhang. Karena jika busana tari Tandhang hanya berupa pakaian adat yang dimana sudah sering dilihat dan diketahui banyak orang maka akan menimbulkan kebosanan bagi yang melihat walaupun gerakan yang ditampilkan menarik. Pihak sanggar juga harus memperhatikan nilai estetika didalamnya. Saat ini busana tari Tandhang yang dimiliki Sanggar Tarara kurang lebih terdapat tiga dengan model dan warna yang berbeda yaitu, hitam emas, kuning, dan merah.

\subsection{Peranan Sanggar Tarara dalam Pelestarian Tari Tandhang di Kabupaten Bangkalan}

\subsubsection{Pelatihan Tari}

Pelatihan tari merupakan salah satu upaya dalam pelestarian tari Tandhang. Pelatihan ini biasanya dilakukan di Sanggar Tarara. Selain di sanggar tari juga diajarkan di beberapa sekolah sebagai ekstrakulikuler. Dalam pelatihan tari terdapat dua ketegori yaitu kategori anak-anak dan kategori remaja. Dalam kategori anak-anak yaitu setiap hari Selasa dan Jum'at sedangkan untuk ketegori Remaja yaitu setiap hari Rabu dan Minggu. Selain pembagian kategori ketika latihan murid pun masih akan dibagi lagi kedalam tiga kelompok yaitu pemula, kelas A, kelas B, dan kelas C berdasarkan dari tingkat yang lebih rendah ke yang tinggi. Selain pada saat hari latihan, di hari yang tidak terdapat latihan pihak sanggar juga membuka privat latihan tari. Biasanya pelatih akan mendatangi kediaman muridnya. Pelatihan ini juga tidak hanya untuk anak-anak dan juga remaja tetapi juga kepada guru TK dan SD sebagai upaya pengenalan tari Tandhang. 


\subsubsection{Menampilkan dalam Sebuah Acara}

Upaya selanjutnya yaitu menampilkan tari Tandhang pada sebuah acara. Sanggar Tarara membuka jasa penampilan seni untuk acara seperti pernikahan, hajatan, penyambutan tamu, lomba, hari jadi Bangkalan, dan lain-lain. Bahkan tari Tandhang saat ini sudah menjadi icon Bangkalan sebagai tari khas Bangkalan. Maka dari itu tari ini juga sering ditampilkan ketika penyambutan tamu penting di Bangkalan. Bukan hanya penyambutan tamu saja melainkan juga pembukaan dalam acara seperti perlombaan. Pada saat ini tari Tandhang lebih sering ditampilkan dalam acara pernikahan karena memang banyak permintaan dari acara pernikahan.

Sanggar Tarara merupakan wadah dan pendukung bagi kesenian yang ada di Bangkalan. Sanggar ini digunakan sebagai tempat berkumpul dan tempat melakukan kegiatan seni. Sanggar adalah suatu tempat atau sarana yang digunakan oleh suatu komunitas atau sekumpulan orang untuk melakukan suatu kegiatan (Purnama, 2015: 462). Selain itu sanggar Tarara merupakan pendidikan non formal di bidang kesenian jadi sanggar ini menjadi suatu sarana sebagai tempat kegiatan belajar dibidang seni dan juga sebagai tempat untuk mencetak orang-orang yang berkesenian. selain itu sanggar adalah suatu tempat atau sarana yang digunakan oleh suatu komunitas atau suatu kelompok orang atau masyarakat untuk melakukan kegiatan. Sanggar identik dengan kegiatan belajar pada suatu kelompok masyarakat yang mengembangkan suatu bidang tertentu termasuk seni tradisional (Pujiwiyana dalam Pertiwi, Suntoro \& Nurmalisa, 2017).

Tari Tandhang dalam prosesnya memiliki pemikiran jangka panjang yaitu melestarikan dan mewariskan unsur budaya yang ada sebelumnya sehingga nilai dan pesan dalam Sandur tidak hilang dan punah akibat perkembangan zaman melainkan selalu ada dan mengikuti perkembangan zaman. Pemahaman mengenai revitalisasi kesenian tradisi, harus disertai dengan pemikiran jangka panjang serta ke arah proses pewarisan unsur tersebut kepada generasi muda, sehingga keberadaan kesenian tradisi dapat terhindar dari kepunahan dan prosesnya dapat berjalan seiring perkembangan IPTEK (Tindaon, 2012) . Dalam menghadapi perubahan budaya saat ini hal yang perlu dilakukan adalah dengan melakukan eksplorasi yang bersifat inventif, inovasi yang rasional, dan bisa berlangsung secara terus menerus dan pada akhirnya akan memperkaya budaya kita (Tindaon, 2012).

Tari Tandhang sebagai salah satu tari kreasi baru yang bersumber dari kesenian tradisional perlu dilestarikan agar tidak hilang akibat perkembangan zaman yang semakin maju dan semakin modern sehingga meninggalkan hal-hal yang berbau tradisonal. Pelestarian tersebut menjadi salah satu usaha Sanggar Tarara agar tari Tandhang bisa diterima oleh masyarakat luas dan disukai oleh beragai kalangan sehingga bisa bersaing dengan tari modern. Pelestarian sebagai kegiatan atau yang dilakukan secara terus menerus, terarah dan terpadu guna mewujudkan tujuan tertentu yang mencerminkan adanya sesuatu yang tetap dan abadi, bersifat dinamis, luwes, dan selektif. Pelestarian budaya adalah upaya untuk mempertahankan nilai-nilai seni budaya, nilai tradisional dengan mengembangkan perwujudan yang bersifat dinamis, luwes dan selektif, serta menyesuaikan dengan situasi dan kondisi yang selalu berubah dan berkembang (Hildigardis, 2019: 171-172).

Pelestarian yang dilakukan oleh Sanggar Tarara yaitu dengan memberikan pelatihan tari Tandhang dan menampilkan tari Tandhang dalam berbagai acara. Pelatihan tersebut tidak hanya dilakukan dilokasi sanggar saja tetapi juga dibeberapa sekolah yang telah memiliki kerja 
sama dengan Sanggar Tarara serta ada juga yang dilakukan di rumah murid yang meminta pelatihan privasi. Pelatihan adalah adalah proses pembelajaran yang lebih menekankan praktek dari pada teorinya yang dilakukan seseorang atau kelompok dengan menggunakan pendekatan berbagai pembelajaran dan bertujuan meningkatkan kemampuan dalam satu atau beberapa jenis keterampilan (Santoso, 2010). Terkadang ada batasan yang ditarik antara pelatihan dengan pengembangan yang bersifat lebih luas dalam cangkupan serta memfokuskan pada individu untuk mencapai kemampuan baru yang berguna baik bagi kegiatan sekarang maupun nanti.

Kemudian penampilan tari Tandhang sebagai salah satu usaha pelestarian dilakukan diberbagai acara seperti event-event, perlombaan, hajatan, pernikahan, penyambutan tamu penting Bangkalan dan lain sebagainya. Tetapi saat ini tari Tandhang lebih sering ditampilkan dalam acara pernikahan. Penampilan tari Tandhang ini selain sebagai usaha pelestarian juga sebagai hiburan seni bagi masyarakat. Seni pertunjukan tampil sebagai ungkapan kepentingan yang berlainan. Kepentingan tari sebagai seni pertunjukan antara lain sebagai tontonan, hiburan, sarana propaganda atau penyampai pesan tertentu, terapi fisik, maupun psikis dan sebagai kelengkapan upacara yang juga merupakan tujuan yang digunakan untuk mewujudkan keberagaman bentuknya (Ew dalam Kailani, Murcahyanto \& Mariadah, 2001) . Dalam proses penampilan tari biasanya penari akan latihan terlebih dahulu bahkan akan lebih sering melakukan latihan. Hal ini dilakukan agar penari saat menampilkan tari Tandhang bisa lebih siap dan kompak. Setelah itu ketika penampilan tari telah selesai biasanya akan ada evaluasi yang dilakukan baik disampaikan langsung atau melalui penanyangan video penampilan tari yang telah dilakukan.

Pelestarian tari Tandhang oleh sanggar Tarara dilakukan secara terus menerus, terarah dan terpadu agar tari ini bisa dikenal oleh masyarakat luar dan bisa diterima sehingga nilai dan pesan dalam Sandur tetap tersampaikan dan tidak hilang melainkan selalu ada sebagai pengingat dan renuangan bagi orang Madura ditengah-tengah masuknya budaya luar yang mempengaruhi kepribadian orang Madura. Seperti yang terlihat saat ini bahwa masyarakat madura sudah banyak melenceng dari nilai-nilai seperti anak-anak yang melawan dan tidak menghormati orang tuanya, kurangnya tatakrama terhadap orang lain, meningkatnya kasus kejahatan dan lainnnya. Pelestarian budaya adalah upaya untuk mempertahankan nilai-nilai seni budaya, nilai tradisional dengan mengembangkan perwujudan yang bersifat dinamis, luwes dan selektif, serta menyesuaikan dengan situasi dan kondisi yang selalu berubah dan berkembang (Hildigardis, 2019: 171-172).

\subsection{Hambatan-Hambatan Sanggar Tarara dalam Pelestarian Tari Tandhang di Kabupaten Bangkalan}

\subsubsection{Keterlambatan}

Keterlambatan kehadiran siswa merupakan salah satu hal yang menjadi hambatan dalam proses latihan. Bahkan keterlambatan ini juga bisa menjadi salah satu hal yang parah jika sering dilakukan. Hal ini dikarenakan pelatihan tari hanya dilakukan dua kali dalam seminggu dan hanya satu jam setengah saja lama latihannya yaitu dari jam setengah empat sampai jam lima sore. Selain itu pelatihan tari juga terkadang tidak diadakan jika terdapat acara lain seperti lomba atau penampilan lainnya. Maka dari itu keterlambatan akan mempengaruhi target pemberian materi yang akan diberikan pelatih. 


\subsubsection{Kemampuan Anak yang Bereda}

Kemapuan memahami materi dan menguasai gerakan tiap anak tidak dapat disama ratakan. Hal ini karena kemampuan tiap anak pada alamiahnya memang berbeda-beda. Tetapi hal ini juga menjadi hambatan selain dari keterlambatan. Perbedaan kemampuan ini juga berpengaruh terhadap pemberian materi yang tidak sesuai target.

\subsubsection{Rasa Malas}

Rasa malas merupakan persoalan yang dapat membuat seseorang enggan melakukan sesuatu. Bahkan tidak ada seorangpun yang tidak pernah merasakan malas untuk melakukan suatu hal. Hal ini menjadi salah satu penyebab murid akan melewati latihan mereka ataupun sengaja untuk datang terlambat. Sehingga menjadi hambatan baik dalam proses latihan maupun proses pengembangan anak tersebut.

\subsubsection{Kurangnya Minat}

Kurangnya minat masyarakat terhadap tari Tandhang di Kabupaten Bangkalan menjadi salah satu hambatan. Hal tersebut terjadi akibat berbagai faktor diantaranya banyaknya budaya luar yang semakin masuk seiiring dengan perkembangan zaman dan sebagian masyarakat memiliki pandangan yang berbeda terhadap tari. Perkembangan zaman yang membawa masuk budaya luar pada kenyataannya bukan hanya saat ini saja melainkan sudah terjadi sejak lama. Budaya tari modern jika dilihat lebih banyak diminati karena dianggap keren dari pada budaya tradisional.

\subsubsection{Perbedaan Pendapat Masyarakat}

Terdapat perbedaan pendapat dari masyarakat terhadap kesenian tari yaitu masyarakat menganggap bahwa seni tidak sejalan dengan kaidah islam, walaupun ada juga masyarakat yang mempunyai pandangan berbeda terhadap seni khususnya seni tari. Hal inilah yang masih menjadi pro-kontra dan perdebatan diantara pelaku seni dan masyarakat di Bangkalan terlebih Bangkalan dikenal sebagai kota shalawat dan dzikir.

Menurut temuan peneliti hambatan yang dihadapi oleh Sanggar Tarara dalam pelestarian tari Tandhang berasal dari dua faktor yaitu Faktor eksternal dan Faktor internal. Hambatan tersebut membuat pelaksanaan pelestarian tari Tandhang di Kabupaten Bangkalan menjadi terganggu. Hambatan adalah suatu hal yang bersifat negatif yang dapat menghambat atau menghalangi kegiatan yang dilakukan oleh seseorang (Suyedi \& Indrus , 2019: 124). Hambatan ini menjadi sebuah rintangan seseorang dalam melakukan kegiatan tertentu Jadi hambatan yang dalam pelestarian tari Tandhang merupakan seuatu yang menjadikan pelestarian tari tersebut menjadi terhambat dan tidak berjalan dengan lancar.

Hambatan yang terjadi akibat Faktor internal tersebut rata-rata berasal dari murid Sanggar Tarara seperti keterlambatan, kemampuan anak yang berbeda dan adanya rasa malas merupakan permasalahan yang menjadi hambatan yang dihadapi Sanggar Tarara dalam pelestarian tari Tandhang di Kabupaten Bangkalan. Pelatih tari mengatakan bahwa faktor keterlambatan merupakan hal yang paling parah karena dapat mempengaruhi pemberian materi. 
Sedangkan hambatan yang berasal dari Faktor eksternal yang yaitu kurangnya minat untuk belajar tari akibat masuknya budaya luar yang disebabkan baik oleh globalisasi, modernisasi dan perkembangan zaman. Budaya asing tersebut membuat budaya asli semakin meredup. Minat masyarakat terutama anak muda lebih banyak pada tari modern yang dianggap tidak kuno sehingga rasa percaya diri mereka lebih tinggi bila mempelajari tari modern. Selain budaya luar yang masuk, perbedaan pendapat yang terjadi di masyarakat juga menjadi salah satu hambatan karena menyebabkan adanya perebadaan pandangan terhadap tari. perbedaan pendapat mengenai tari ini didasari oleh masyarakat madura yang selalu berpegang teguh pada agama sehingga membuat mereka memiliki penilaian sendiri terhadap tari.

Jadi hambatan yang dihadapi oleh Sanggar Tarara berasal dari dua faktor yaitu Faktor internal dan Faktor eksternal. Faktor internal melingkupi hal yang terjadi di dalam Sanggar yaitu keterlambatan, perbedaan kemampuan anak dan rasa malas sedangkan Faktor eksternal terjadi akibat lingkup yang lebih luas yaitu berasal dari luar Sanggar Tarara. penyebabnya yaitu masuknya budaya luar dan perbedaan pendapat pada masyarakat mengenai boleh tidaknya tari. Semua hambatan tersebut membuat proses pelestarian tari Tandhang di Kabupaten Bangkalan terhambat atau tidak lancer.

\subsection{Solusi dari Hambatan-Hambatan dalam Pelestarian Tari Tandhang di Kabupaten Bangkalan}

\subsubsection{Mengingatkan Latihan}

Mengingatkan merupakan salah satu cara agar anak tidak lupa untuk datang latihan dengan tidak terlambat. Dengan cara mengingatkan inilah merupakan salah satu upaya agar murid yang sering terlambat bisa datang tepat waktu. Pelatih biasanya akan mengingatkan melalui group whattapp yang sudah ada. Terlebih lagi pada saat ini kebanyakan mereka semua memiliki smartphone sehingga memudakhan pelatih dalam memberikan informasi baik berupa latihan ataupun hal lainnya. Walaupun masalah keterlambatan tidak sepenuhnya bisa dihilangkan karena faktor-faktor tertentu seperti jadwal murid yang bertabrakan dengan jadwal latihan maka pelatih memberikan keringanan dengan diperbolehkan datang terlambat dengan memberitahu pelatih. Karena itu pelatih dalam menghadapi keterlambatan ini selain terus mengingatkan juga terus bersabar dan terus melakukan proses.

\subsubsection{Membagi Murid Berdasarkan Kelompok}

Pembagian kelompok ini mempermudah pelatih dalam memberikan materi kepada murid. Pelatihan tari Sanggar Tarara memiliki dua kategori. Kategori anak-anak biasanya diisi untuk mereka yang masih duduk di jenjang SD dan bawahnya. Kemudian untuk kategori remaja biasanya diisi untuk mereka yang berjenjang SMP dan keatasnya. Ditiap kategori tersebut terbagi lagi menjadi empat kelas yaitu kelas pemula, kelas a, kelas b, dan kelas c diurutkan dari yang rendah ke yang ketinggi. Untuk kelas c ini diisi oleh mereka yang telah lama mengikuti pelatiah dan lebih menguasai materi.

\subsubsection{Memotivasi Diri}

Memotivasi diri merupakan hal yang penting agar menumbuhkan semangat bagi murid agar nantinya bisa membawa perubahan sikap maupun peningkatan mutu. Dalam hal ini 
pelatih memiliki peran dalam memberikan motivasi-motivasi kepada murid. Selain pelatih, diri mereka sendirilah yang harus bisa ikut memotivasi juga. Mereka harus bisa melawan rasa malas dan menyadari bahwa kesuksesan tidak didapat dari bermalas-malasan saja melainkan harus ada kerja keras yang dilakukan.

\subsubsection{Menarik Minat}

Untuk menarik minat masyarakat terhadap tari Tandhang yang saat ini tengah bersaing dengan budaya luar yaitu dengan menyesuaikan kondisi yang ada. Penyesuaian tersebut dilakukan terhadap gerak dan busana yang dipakai. Pada gerak tari Tandhang saat ini sudah disesuaikan namun tidak memiliki banyak perubahan terhadap gerak yang awalnya. Sedangkan penyesuaian busana tari yaitu dengan membuat beberapa model dan warna busana yang berbeda. Tidak lagi menggunakan baju khas masyarakat Madura karena akan terlihat membosankan.

\subsubsection{Menghargai Perbedaan Pendapat}

Perbedaan pendapat merupakan hal yang biasa terjadi. Maka perbedaan pendapat terhadap masyarakat terkait seni, ketua Sanggar Tarara yaitu bapak Sudarsono tidak menyalahkan melainkan menghargai setiap pendapat yang ada. Karena memang pro-kontra terhadap seni dan kaidah Islam sudah ada sejak lama.

Menurut temuan peneliti solusi yang diambil oleh Sanggar Tarara merupakan tindakan untuk menyelesaikan hambatan atau permasalahan yang ada dalam pelestarian tari Tandhang di Kabupaten Bangkalan. solusi tersebut menggunakan strategi dan pertimbangan agar tetap sesuai dengan aturan dan tidak mengutamakan pendapat pribadi. Solusi adalah cara atau jalan yang diginakan untuk memecahkan atau menyelesaikan masalah tanpa adanya tekanan. Tekanan yang dimaksud disini yaitu dalam mencari solusi tidak memaksakan pada pendapat pribadi melainkan berpedoman pada kaidah atau aturan yang ada (Chatib, 2011).

Solusi yang dipilih oleh Sanggar Tarara dalam menghadapi hambatan dari dalam bukan hanya untuk menyelesaikan satu hambatan atau permasalahan saja melainkan saling berkaitan. Mengingatkan latihan di group whatsapp merupakan suatu tindakan untuk meminimalisir keterlambatan. Selain mengingatkan pelatih juga memberikan motivasi agar murid yang merasa malas dan sering datang terlambat bisa termotivasi untuk datang tepat waktu. Tetapi untuk keterlambatan yang disebabkan oleh kesibukan murid akan diberikan toleransi keterlambatan karena jika disebabkan oleh kesibukan jadwal maka pelatih tidak bisa memaksakan.

Kemudian solusi untuk hambatan kemampuan murid yang berbeda-beda, Sanggar Tarara menerapkan sebuah stategi. Strategi tersebut yaitu dengan membagi murid menjadi dua kategori yaitu anak-anak dan remaja. Kemudian dalam masing-masing kategori akan dibagi lagi menjadi empat kelas yaitu pemula, kelas A, kelas B, dan Kelas C. Untuk murid yang baru bergabung dan baru mengenal tari akan dimasukkan dalam kelas pemula kemudian akan berlanjut ke kelas A, kelas B, dan kelas C. Strategi ini diambil untuk mempermudah pelatih dalam memberikan dan membagi materi kepada murid.

Selanjutnya solusi yang diambil Sanggar Tarara dalam menghadapi hambatan dari luar akibat banyaknya budaya luar yang masuk dan menyebabkan hilangnya minat anak muda 
terhadap kesenian tradisional terutama tari Tandhang yaitu dengan menyesuaikan busana tari Tandhang agar menarik ketika ditampilkan. Sedangkan untuk mengatasi perbedaan pendapat yaitu dengan menerima perbedaan pendapat yang ada. Karena tujuan dari Sanggar Tarara yaitu melestarikan budaya sendiri dan juga budaya yang sudah turun temurun yang mulai terlupakan oleh masyarakat agar tidak sepenuhnya hilang.

Solusi yang diambil dalam menghadapi hambatan yang ada dalam prosesnya diambil dengan melakukan pertimbangan dan strategi terlebih dahulu. Tujuan dari pertimbangan agar pendapat yang diambil bukan merupakan pendapat pribadi. Begitupun strategi yang diambil bertujuan untuk bisa melakukan pelestarian tari Tandhang dalam jangka panjang sehingga tujuan dari pelestarian dapat terwujud. Strategi adalah sebuah tindakan aksi atau kegiatan yang dilakukan oleh seseorang atau perusahaan untuk mencapai sasaran atau tujuan baik jangka pendek maupun jangka panjang yang telah ditetapkan dalam menghadapi masalah atau hambatan yang datang baik dari dalam maupun luar perusahaan (Zulfajri, 2017: 85).

Jadi solusi yang diambil oleh Sanggar Tarara sudah terlebih dahulu dipikirkan secara baik dan bersama. Tidak ada unsur pemaksaan dalam prosesnya melainkan dijalankan secara sabar oleh pelatih. Strategi pembagian kategori dan kelas juga berjalan dengan baik dan hasilnyatanya dapat membantu pelatih dalam membagi serta memberikan materi kepada murid.

\section{Simpulan}

Nilai-nilai yang terdapat dalam tari Tandhang diambil dari pengalaman dan kepribadian orang Madura dalam menjalani kehidupannya sehari-hari dan telah menjadi nilai filosofi. Nilainilai tersebut yaitu dinamis, gigih dalam berusaha, menjaga harga diri, menghormati orang lain, dan mendahului berbuat baik. Gerakan pada tari Tandhang digarap dari kesenian Sandur sehingga mirip dengan gerakan pencak silat. Gerakan tersebut memiliki makna yang menggambarkan bahwa orang Madura terlihat keras namun sebenarnya lembut.

Peranan Sanggar Tarara dalam pelestarian tari Tandhang di Kabupaten Bangkalan yaitu dengan pelatihan tari baik di lokasi sanggar, sekolah sebagai kegiatan ekstrakulikuler, dan rumah murid sebagai kegiatan privasi tari. Kemudian dengan pementasan tari diberbagai acara seperti event-event, perlombaan, hajatan, pernikahan, penyambutan tamu penting Bangkalan, dan lain-lain. Pementasan tari Tandhang selain sebagai usaha pelestarian juga sebagai hiburan bagi masyarakat yang melihatnya.

Hambatan-hambatan yang dihadapi oleh Sanggar Tarara berasal dari dua faktor yaitu Faktor eksternal dan Faktor internal. Faktor internal yang menjadi hambatan dalam pelestarian tari tandhang yaitu berasal dari murid sanggar sendiri seperti keterlambatan, kemampuan, dan rasa malas. Kemudian Faktor eksternal terjadi akibat budaya-budaya luar yang masuk terutama tari modern dan menarik minat masyarakat terutama anak muda dan adanya perbedaan pendapat mengenai budaya tari dalam masyarakat Madura.

Solusi yang diambil oleh Sanggar Tarara dalam menghadapi hambatan yang ada yaitu, untuk perkembangan zaman yang semakin maju Sanggar Tarara juga membuat pengembangan terhadap busana tari Tandhang agar bisa bersaing dengan tari modern dengan tanpa meninggalkan unsur tradisionalnya dan menerima perbedaan pendapat yang ada dalam masyarakat mengenai budaya tari. Sedangkan untuk hambatan yang berasal dari murid sanggar itu sendiri seperti keterlambatan, kemampuan, dan rasa malas biasanya pelatih akan 
memanfaatkan media sosial whatsapp group untuk mengingatkan dan memberikan motivasi kepada murid. Disamping itu yang dilakukan pelatih adalah sabar dan terus melakukan dengan ikhlas.

\section{Daftar Rujukan}

Adisusilo, S. (2012). Pembelajaran Nilai Karakter Konstruktivisme dan VCT Sebagai Inovasi Pendekatan Pembelajaran Afektif. Jakarta: Rajagrafindo Persada.

Chatib, M. (2011). Gurunya Manusia: Menjadikan Semua Anak Istimewa dan Semua Anak Juara. Bandung: Mizan Pustaka.

Fhata, M. Supadmi, T., \& Ismawan. (2018). Peranan Sanggar Putroe Jeumpa Keubiru dalam Melestarikan Tari Pho di Desa Blang Kuala Kecamatan Meukek Aceh Selatan. Jurnal Ilmiah Mahasiswa Program Studi Pendidikan Seni Drama, Tari dan Musik, 3(1), 68-76.

Hadi, S. Y. (2018). Revitalisasi Tari Tradisional. Dwi-Quantum.

Hartono. (2000). Peranan Sanggar dalam Pengembangan Seni Tari. Yogyakarta: Lentera Budaya.

Hidayat, A. R. (2020). Metaepistemologi Worldview Orang Madura. Pamekasan: Duta Media Publishing.

Hildigardis, M. I. N. (2019). Upaya Melestarikan Budaya Indonesia di Era Globalisasi. Jurnal Sosiologi Nusantara, 5(1), 165-175. DOI: https://doi.org/10.33369/jsn.5.1.65-76.

Kailani, A. Murcahyanto, H., \& Maridah. (2020). Bentuk Pertunjukan Drama Tari Bejoraq. Jurnal Pendidikan Sejarah dan Riset Sosial Humaniora (KAGANGA), 3(2), 62-69.

Khutniah, N., \& Veronica E. I. (2012). Upaya Mempertahankan Eksistensi Tari Kridajati Di Sanggar Hayu Budaya Kelurahan Pengkol Jepara. Jurnal Seni Tari, 1(1), 9-21.

Lantaeda, S. B. Lengkong, F. D . J., \& Ruru J. M. (2017). Peran Bandan Perencanaan Pembangunan Daerah dalam Penyusunan RPJMD Kota Tomohon. Jurnal Administrasi Publik, 4(48), 1-9.

Moleong, Lexy. (2014). Metodologi Penelitian Kualitatif. Edisi Revisi. Bandung: PT Remaja Rosdakarya.

Pertiwi, T. C. Suntoro, I., \& Nurmalisa, Y. (2017). Peranan Sanggar Budaya Bandakh Makhga dalam Pelestarian Nilai Budaya Lampung di Sukadanaham. Jurnal FKIP Unila, 5(4), 1-16.

Purnama, Y. (2015). Peranan Sanggar dalam Melestarikan Kesenian Tradisional Betawi. Jurnal Penelitian Sejarah dan Budaya, 7(3), 461-467. DOI: http://dx.doi.org/10.30959/patanjala.v7i3.112.

Republik Indonesia. (2017). Undang-Undang No. 5 tahun 2017 Tentang Pemajuan Kebudayaan. Lembaran Negara Nomer 6055.

Salfia, N. (2015). Nilai Moral dalam Novel 5 CM Karya Donny Dhirgantoro. Jurnal Humanika, 3(15), 1-18.

Santoso, B. (2010). Skema dan Mekanisme Pelatihan, Panduan Penyelenggaraan Pelatihan. Jakarta: Yayasan Terumbu Karang Indonesia (TERANGI).

Soedarsono. (1978). Tari-Tarian Indonesia I. Jakarta: Balai Pustaka.

Sutiyono, \& Seriati, N. N. (2013). Pemberdayaan Masyarakat Desa Dalam Melaksanakan Revitalisasi Budaya Lokal “Bersih Desa” Di Ketingan, Sleman. Jurnal Penelitian Humaniora, 18(1), 30-38.

Suyatno. (2012). Nilai, Norma, Moral, Etika dan Pandangan Hidup Perlu Dipahami oleh Setiap Warga Negara dalam Kehidupan Berbangsa dan Bernegara. PKn Progresif, 7(1), 34-44.

Suyedi, S. S., \& Idrus, Y. (2019). Hambatan-Hambatan Belajar yang Mempengaruhi Hsil Belajar Mahasiswa dalam pembelajaran Mata Kuliah Dasar Desain Jurusan IKK FPP UNP. Gorga Jurnal Seni Rupa, 8(1). 120128.

Tindaon, R. (2012). Kesenian Tradisional dan Revitalisasi. Jurnal Ilmu Pengetahuan dan Karya Seni, 14(2), 148280. DOI: http://dx.doi.org/10.26887/ekse.v14i2.225.

Zulfajri, T. (2017). Strategi Pengelolaan Pelatihan Pada Kelompok Teater (Studi Kasus Pengajian Tubuh Tony Broer). Jurnal Tata Kelola Seni, 3(2), 83-92. 